\title{
Turkish monetary policy and components of aggregate demand: a VAR analysis with sign restrictions model
}

\section{Hakan Berument , Zulal Denaux \& Yeliz Yalcin}

To cite this article: M. Hakan Berument , Zulal Denaux \& Yeliz Yalcin (2012) Turkish monetary policy and components of aggregate demand: a VAR analysis with sign restrictions model, Applied Economics, 44:36, 4787-4798, DOI: 10.1080/00036846.2011.564151

To link to this article: http://dx.doi.org/10.1080/00036846.2011.564151

曲 Published online: 08 Sep 2011.

Submit your article to this journal $\widetilde{ }$

Џلll Article views: 283

Q View related articles $\longleftarrow$

Citing articles: 2 View citing articles ๘ 


\title{
Turkish monetary policy and components of aggregate demand: a VAR analysis with sign restrictions model
}

\author{
M. Hakan Berument ${ }^{\mathrm{a}}$, Zulal Denaux ${ }^{\mathrm{b}, *}$ and Yeliz Yalcin ${ }^{\mathrm{c}}$ \\ ${ }^{a}$ Department of Economics, Bilkent University, 06800 Ankara, Turkey \\ ${ }^{\mathrm{b}}$ Department of Marketing and Economics, Valdosta State University, \\ 31698 Valdosta, GA, USA \\ ${ }^{\mathrm{c}}$ Department of Econometrics, Gazi University, 06500 Ankara, Turkey
}

This article estimates the effects of monetary policy on components of aggregate demand using quarterly data on Turkish economy from 1987-2008 by means of structural Vector Autoregression (VAR) methodology. This study adopts Uhlig's (2005) sign restrictions on the impulse responses of main macroeconomic variables to identify monetary shock. This study finds that expansionary monetary policy stimulates output through consumption and investment in the short-run. However, expansionary monetary policy is ineffective in the long-run.

Keywords: monetary policy; vector autoregression; agnostic identification

JEL Classification: C32; E52; E20

\section{Introduction}

The effects of monetary policy changes on macroeconomic variables have always been of interest to macroeconomists. Most of these studies look at the effects of monetary policy changes on total output, real exchange rate and general price level (Jang and Ogaki, 2004; Berument, 2007; Dickinson and Liu, 2007). However, these changes on macroeconomic variables may be due the state of the economy rather than to monetary policy changes. Therefore, it is not easy to extract changes on monetary policy variables. A number of studies have used different identification schemes to identify monetary policy shocks. Sims $(1972,1980)$ proposes to use a Vector Autoregression (VAR) method to capture the monetary policy stance.
To be specific, he suggests using the innovation in money aggregate or interest rate as a measure of monetary policy change. Christiano and Eichenbaum (1992) argue that changes in broad aggregates reflect both demand and supply shocks. The interest rate is also considered as an innovation (Bernanke and Blinder, 1992; Sims, 1992). There seems to be little consensus on what kind of variables should be used as an indicator of monetary policy (Rafiq and Mallick, 2008). Unlike these studies, Uhlig (2005) identifies a monetary policy shock by directly imposing the sign restrictions on impulse responses of selected variables for several periods following the shock.

There are several advantages of this approach. First, by construction, impulse responses of a shock

*Corresponding author. E-mail: zsdenaux@valdosta.edu 
should agree with received opinion on what these signs should be for a period of time. Second, because of identifying monetary policy shocks using impulse responses for several periods following the shock, a wide range of monetary policy shocks can be captured. Third, impulse responses are drawn from the posterior distribution of the reduced form VAR covariance matrix and coefficients, and from the set of structural matrices consistent with the assumed sign restrictions. That is, on the evidence of simulation experiments, it performs well relative to identification methods based on contemporaneous zero restrictions (Mountford, 2005).

In this study, in order to identify the effects of monetary policy shocks, Uhlig's (2005) sign restriction methodology is used. We assume that an expansionary monetary shock does not lead to increase in interest rate, but decrease in both exchange rate and money aggregate in the first two quarters following the shock. Expansionary monetary policy is associated with a higher money aggregate and a lower interest rate. Lowering interest rates encourage investment and consumption due to the lower cost of borrowing. Firms, finding that cost of borrowing has decreased, increase their investment expenditure. Likewise, consumers facing lower borrowing cost increase their purchases of consumption goods. Moreover, expansionary monetary policy increases consumption with higher wealth of individuals through increasing the value of their bond holdings due to the lower interest rate. The expansionary monetary policy also causes increase in financial and physical asset prices. A rise in asset prices increases the ratio of liquid financial assets to household debt, thereby reducing the probability of financial distress and therefore increasing consumption (Mishkin, 2001, 2006). According to Tobin's $q$ theory, the expansionary monetary policy reduces interest rates, making bonds less attractive relative to equities, thereby raising the price of equities. Thus, increase in financial wealth raises consumption (Tobin, 1969; Mishkin, 2001, 2006). Expansionary monetary policy also affects international trade. Higher income level increases import (income effect) but higher exchange rate (depreciation) coupled with expansionary monetary policy increases export and decreases import (expenditure switching effect). Then, the net effect on trade balance will depend upon the relative magnitudes of income and expenditure switching effects. On the other hand, opportunistic government likes to increase its spending when it is possible, especially just before elections or when there is a positive output gap. However, increase in spending increases interest rates. Expansionary monetary policy provides this chance when the interest rates are lower. Thus, we expect higher government spending with expansionary monetary policy. On the other hand, if money is neutral, then monetary policy should not have any lasting effect on output and its component in the long-run (Friedman, 1969).

Since it is an interesting small open case-study, the Turkish economy is investigated in this study. For example, The Central Bank of the Republic of Turkey (CBRT), unlike the some other central banks, was involved in an active monetary policy. Moreover, Turkey has been experiencing a high and persistent level of inflation without running into hyperinflation. The relationships between the money aggregates and macroeconomic variables are more visible because of the high variability of monetary policy changes and the higher level of price level variability. In addition, Turkey has relatively well developed and liberal financial markets; in particular, money, foreign exchange and bond markets operate without any heavy regulations. Under thin markets, interest rates and exchange rates might move with the initiations of a few speculators (or manipulators) (Berument, 2007).

This article aims to investigate how the monetary policy changes on the basic components of aggregate demand: consumption, investment, government spending and net trade balance by employing Uhlig's (2005) methodology using quarterly data from 1987:Q1 to 2008:Q3 for Turkey. To the best of our knowledge, this is the first study that attempts to understand how the monetary policy affects each component of aggregate demand using Uhlig's (2005) sign restriction method on the short and long horizons.

This article is organized as follows. The VAR model and identification methodology are given in Section II. Section III describes the identifying sign restrictions for monetary policy shock and description of VAR model used in the study with a detail explanation of data. Section IV tabulates the empirical findings using Uhlig's (2005) sign restriction methodology. Section V concludes with a discussion of the main findings and their implications.

\section{The Methodology}

In this article we identify the monetary policy shock using the sign restriction, as proposed by Uhlig (2005). In order to describe the relationship between structural VAR's one-step ahead prediction errors and structural macroeconomic shocks, the sign identification procedure starts with a reduced 
form VAR:

$$
Y_{t}=c(t)+B_{1} Y_{t-1}+\cdots+B_{k} Y_{t-k}+u_{t}
$$

where $Y_{t}$ is an $(m \times 1)$ vector containing each of the $m$ variables included in the VAR model, $B_{j}$ are coefficient matrices of size $m \times m, c(t)$ contains constant and possible time trend term and $u_{t}$ is the one-step ahead prediction error with variance-covariance matrix $E\left[u_{t} u_{t}^{\prime}\right]=\sum$.

The usual structural VAR approach assumes that the error terms $u_{t}$ are related to the structural macroeconomic shocks, $v_{t}$, via matrix $A$ such that

$$
u_{t}=A v_{t}
$$

where $E\left[v_{t} v_{t}^{\prime}\right]=I_{m}$.

In this study, since only the monetary policy shock, $v^{M P}$, is estimated, the prediction errors in the VAR model are characterized as being decomposed in the following way:

$$
u_{t}=A_{1} v_{t}^{M P}+\tilde{A}^{\prime} \tilde{v}_{t}
$$

where $A_{i}$ is the $i$-th column of the matrix $A, \tilde{A}^{\prime}$ is the $(m \times(m-1))$ matrix of the remaining columns of $A$ and $\tilde{v}$ is the $((m-1) \times 1)$ matrix of the remaining unidentified fundamental shocks. Therefore, all the identified shocks can have an instantaneous effect on all variables. Where, the $j$-th column of $A$ represents the immediate impact on all variables of the $j$-th innovation.

$$
\sum=E\left[u_{t} u_{t}^{\prime}\right]=A E\left[v_{t} v_{t}^{\prime}\right] A^{\prime}=A A^{\prime}, \quad A=\tilde{A} Q
$$

In order to achieve identification, $m(m-1) / 2$ degrees of freedom in specifying $A$ are needed. In the study by Uhlig (2005), $Q$ is an orthogonal and $\tilde{A}$ is the Cholesky decomposition of the estimated matrix of covariance residuals $\hat{\Sigma}\left(\tilde{A} \tilde{A}^{\prime}=\sum\right)$. Thus, determining the free elements in $A$ can be conveniently transformed into the problem of choosing elements in an orthogonal set. $a$ is a column of the matrix $A$ named by an impulse vector if and only if there is an $m$-dimensional vector $\alpha$ of unit length so that

$$
a=\tilde{A} \alpha
$$

where $\alpha$ is a column of the matrix $Q$. Given an impulse vector $a$, it is easy to calculate the appropriate impulse response in the following way. Let $r_{i}(k)$ be the impulse response at the period $k$ to the $i$-th shock obtained by $\tilde{A}$. So, the impulse response for $a$ at horizon $k$ is given as follows:

$$
r_{a}(k)=\sum_{i=1}^{m} \alpha_{i} r_{i}(k)
$$

In the case of a monetary policy shock, the methodology checks whether $a \in A(\hat{B}, \hat{\Sigma}, K)$, by checking the appropriate sign restrictions on the impulse responses for all relevant horizon periods $k$, where $a$ is the monetary policy impulse vector.

The method consists of 'outer-loop draws' and 'inner-loop draws', so Uhlig's (2005) procedure can be summarized as fallows:

Step 1: Estimate the VAR and obtain $\hat{B}$ and $\hat{\Sigma}$

Step 2: Take $n_{1}$ draws from the VAR posterior Normal-Wishart (see Uhlig, 1994, 2005 for details) and, for each of these draws, $n_{2}$ draws $a$ from independent uniform prior that the $m$-dimensional unit sphere.

Step 3: For getting a vector of unit sphere, $\tilde{\alpha}^{*}$, draw each column of $\tilde{A}$ from the $m$-dimensional standard normal distribution, and then normalize its length to unity, $\tilde{\alpha}^{*}=\tilde{\alpha} /\|\tilde{\alpha}\|$.

Step 4: For each draw, calculate $n_{1} \times n_{2},{ }^{1}$ impulse responses $a=\tilde{A} \alpha$ and $r_{a}(k)$ at horizon $k=0, \ldots, K$.

Step 5: Check whether the impulse response functions satisfy the sign restrictions.

Step 6: Keep it if the impulse response satisfy the sign restrictions, otherwise discard it.

Step 7: Collect the $n_{3}^{2}$ impulse responses for each shock using loss function and plot their 16th, 50th and 84th percentiles.

\section{Data, Description of the VAR and Sign Restriction}

In this study, we use quarterly data of interbank interest rate as interest rate, M1 plus Repurchase Agreements (REPO) ${ }^{3}$ as money aggregate, Turkish Lira (TL) value of US dollar as exchange rate, Gross Domestic product (GDP) deflator as prices, GDP as income, the private consumption as consumption, gross fixed capital formation as investment,

\footnotetext{
${ }^{1}$ We take $n_{1}=n_{2}=200$, so there are 40000 draws in total in this study.

${ }^{2}$ We take $n_{3}=100$ in this study.

${ }^{3}$ There are two reasons inluding repo in the measurment of money aggregates. First, most of the repo transactions were overnight providing the most liquid form of money aggregates. Second, most of the agents prefer to repo their savings rather than open deposit accounts because of cosiderably higher repo rates.
} 
government purchase of good and services as government, export of goods and services as export and import of goods and services as import. The quarterly data are obtained from CBRT Electronic Data Delivery System and the estimation period is from 1987:Q1 to 2008:Q3.

All variables are used in logarithms form except the interest rate. In order to choose the specification of the variables in the VAR system, we examine the time series properties of those variables. For the analysis of the multivariate time series that include stochastic trends, the Augmented Dickey Fuller (ADF) (Dickey and Fuller, 1981), Phillips-Perron (PP) (Perron, 1989) and Kwiatkowski, Phillips, Schmidt and Shin (KPSS, 1992) unit root tests are used for determining the order of integration. The null hypothesis of the ADF and PP tests is that a time series contains a unit root, while the KPSS test has the null hypothesis of stationarity. The results of these tests for seasonally unadjusted data are given in Table 1 and the results for seasonally adjusted data are given in Table 2 .

According to results, in general, unit root cannot be rejected at conventional significance levels for all variables. We also use Johansen and Juselius (1990) method to test cointegration among all the variables. Since the trace statistic and the maximum eigenvalue statistic may yield conflicting results, we use both the trace and maximum eigenvalue-type cointegration tests in this study. The appropriate lag length for the VAR level is estimated using Schwarz criterion while maximum lag order is 4 . The results of cointegration tests are presented in Table 3.

The results suggest that the number of statistically significant cointegration vectors is equal to 2 . The variables in our system are nonstationary but cointegrated, therefore, the estimation of the VAR in (log) levels provide consistent estimates (Sims et al., 1990; Lütkepohl and Reimers, 1992). Moreover, in the Bayesian VAR methodology of Sims and Uhlig (1991) and Uhlig (2005) the parameters of VAR in level are estimated. This methodology is robust to the presence of nonstationarity and though it does not impose any cointegrating long-run relationship between the variables, it does not preclude their existence either. Therefore, in our study, the variables in VAR are used in levels.

We use a VAR in GDP, the exchange rate, the interest rate, M1 with REPO $(\mathrm{M} 1+R)$, and the price. The VAR system consists of these five variables at a quarterly frequency from 1987 to 2008, has four lags, constant term, seasonal and break dummies. The dummy variable is included to capture the April 1994 currency crises taking a value of one for the period of 1994:Q1-Q2, zero otherwise. Since the data for REPO are only available from 1995:Q1 and on, we also use a dummy variable taking a value of one for 1995:Q1-2008:Q3, zero otherwise. To examine the effects of monetary policy changes on the component of aggregate demand, the macroeconomic variables consumption, government expenditure, export, import, investment and trade balance - are added in the benchmark VAR model.

This study follows Uhlig's (2005) identification procedure for determining the monetary shock by directly restricting the signs of impulse responses of some variables in the benchmark VAR model for some period. An overview of our sign restrictions on the impulse responses is shown in Table 4. We assume that, following an expansionary monetary shock, the response of interest rate is nonpositive while the responses of exchange rate and money aggregate are nonnegative for the first two quarters after the shock. There is no restriction imposed on the impulse responses of GDP and price. Table 5 summarizes the sign restrictions for identifying monetary policy shock in the existing literature. In this table, there are several restrictions for different types of monetary policy. Moreover, our restrictions are for an expansionary monetary policy and consistent with the literature.

\section{Empirical Results}

In order to assess the effect of monetary policy shocks, we report the impulse responses for 10 periods in Figs 1-7. Figure 1 contains our benchmark impulse responses of exchange rate, price level, interest rate, money aggregate and real income to an expansionary monetary policy shock with sign restriction approach, which satisfies the sign restrictions for the first two quarters after the shock. The responses of exchange rate and money aggregate have been restricted not to be negative and the interest rate has been restricted not to be positive for the first 6 months (two quarters). In Fig. 1 and in the figures that follow we plot the median of impulse responses, as well as the upper and lower bounds represent a one-SD band. The main consequences of an expansionary monetary policy shock can be summarized as follows. First, the effects of loose monetary policy on exchange rate and money aggregate have the expected sign, and are statistically significant for almost three quarters. The immediate increase in the exchange rate is followed by constant decrease until the third quarter, after which this effect dies out and converges to zero. The positive effect on money follows steady decrease until the third quarter, after this the effect becomes permanent. Second, the interest rate reacts 


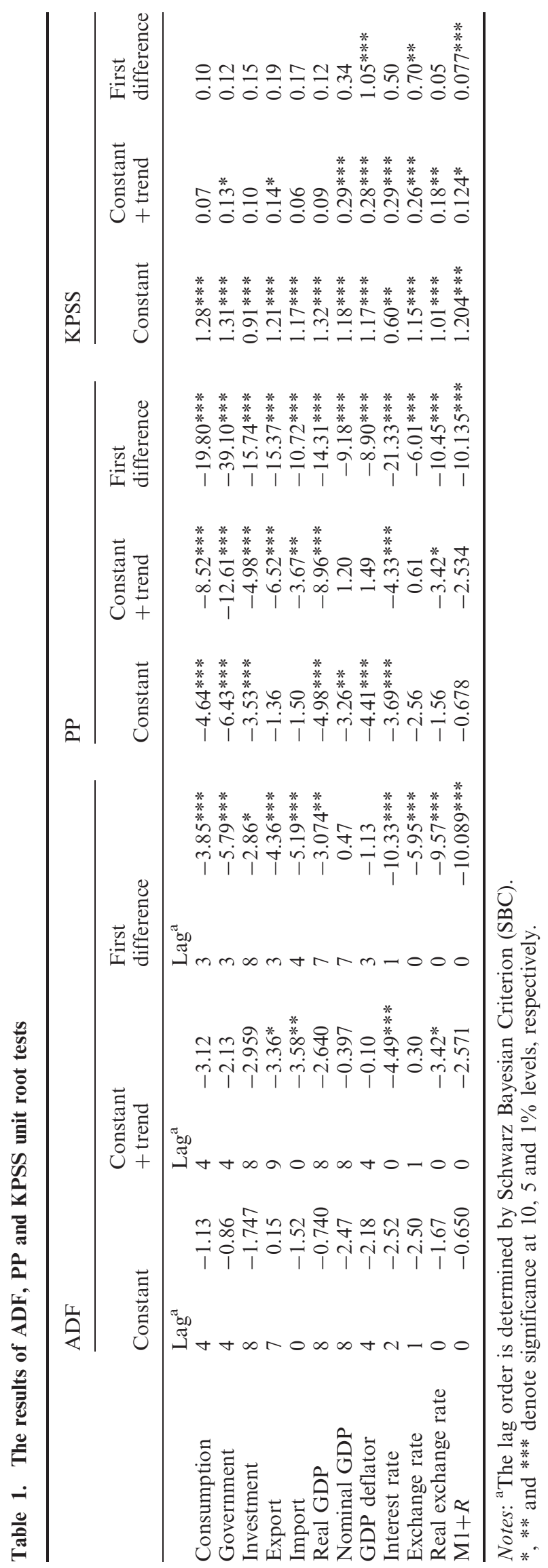


Table 2. Unit root test results for seasonally adjusted data

\begin{tabular}{|c|c|c|c|c|c|c|c|c|c|c|c|c|}
\hline & \multicolumn{6}{|c|}{$\mathrm{ADF}$} & \multicolumn{3}{|l|}{ PP } & \multicolumn{3}{|l|}{ KPSS } \\
\hline & \multicolumn{2}{|c|}{ Constant } & \multicolumn{2}{|c|}{$\begin{array}{l}\text { Constant } \\
+ \text { trend }\end{array}$} & \multicolumn{2}{|c|}{$\begin{array}{l}\text { First } \\
\text { difference }\end{array}$} & Constant & $\begin{array}{l}\text { Constant } \\
+ \text { trend }\end{array}$ & $\begin{array}{l}\text { First } \\
\text { difference }\end{array}$ & Constant & $\begin{array}{l}\text { Constant } \\
+ \text { trend }\end{array}$ & $\begin{array}{l}\text { First } \\
\text { difference }\end{array}$ \\
\hline & & $\mathrm{Lag}^{\mathrm{a}}$ & & $\mathrm{Lag}^{\mathrm{a}}$ & & $\mathrm{Lag}^{\mathrm{a}}$ & & & & & & \\
\hline Consumption & 0 & -1.07 & 0 & -2.30 & 3 & $-5.69 * * *$ & -1.08 & -2.54 & $-8.79 * * *$ & $1.14 * * *$ & 0.08 & 0.06 \\
\hline Government & 4 & -1.10 & 4 & -1.50 & 3 & $-6.06 * * *$ & -0.95 & -2.01 & $-9.67 * * *$ & $1.16^{* * *}$ & $0.22 * * *$ & 0.09 \\
\hline Investment & 1 & -1.77 & 1 & -2.44 & 0 & $-7.62 * * *$ & -1.86 & -2.37 & $-7.61 * * *$ & $0.82 * * *$ & 0.10 & 0.07 \\
\hline Export & 1 & -0.67 & 0 & -2.70 & 0 & $-11.45 * * *$ & -0.90 & -2.79 & $-11.39^{* * *}$ & $1.20 * * *$ & 0.10 & 0.08 \\
\hline Real GDP & 0 & -1.21 & 0 & -2.64 & 3 & $-6.14 * * *$ & -1.21 & -2.89 & $-9.18 * * *$ & $1.17 * * *$ & 0.07 & 0.07 \\
\hline Nominal GDP & 9 & -2.44 & 2 & 1.49 & 5 & -0.08 & $-4.16^{* *}$ & 2.98 & $-3.11 * *$ & $1.18 * * *$ & $0.28 * * *$ & $1.05 * * *$ \\
\hline
\end{tabular}

Notes: ${ }^{\text {a }}$ The lag order is determined by SBC.

$* *$ and $* * *$ denote significance at 5 and $1 \%$ levels, respectively.

Table 3. Johansen's cointegration tests

\begin{tabular}{lcl}
\hline $\begin{array}{l}\text { The number of } \\
\text { cointegrating relations }\end{array}$ & Trace statistic & $\begin{array}{l}\text { Max-Eigen } \\
\text { statistic }\end{array}$ \\
\hline None* & 144.740 & 73.339 \\
& $(0.000)$ & $(0.0000)$ \\
At most $1 *$ & 71.401 & 49.231 \\
& $(0.0001)$ & $(0.0001)$ \\
At most 2 & 22.169 & 14.121 \\
& $(0.2892)$ & $(0.3552)$ \\
At most 3 & 8.048 & 7.910 \\
At most 4 & $(0.4602)$ & $(0.3879)$ \\
& 0.1381 & 0.1381 \\
& $(0.7101)$ & $(0.7101)$ \\
\hline
\end{tabular}

Notes: While maximum lag length is 4 , the order level VAR is estimated as 4 using SBC. Values in parentheses are MacKinnon-Haug-Michelis (1999) $p$-values. Both trace and max-eigenvalue tests indicate 1 cointegrating equation at the $10 \%$ level.

*Denotes significance at the $5 \%$ level.

negatively and immediately to the monetary shock. This temporary decrease in interest rate is significant up to the second quarter. Finally, the findings on the impulse responses of GDP and price level are consistent with the economic literature, which suggests positive increase in both variables for the transition countries (Coricelli et al., 2006; Samkharadze, 2008). A monetary policy shock has positive and significant impact on the real GDP until the third quarters. The effect of the shock on real GDP becomes insignificant after the third quarter. Moreover, the effect of monetary policy on price level is also positive and significant for three quarters peaking at the second quarter, after the initial shock. The positive price increase remains persistent for at least nine quarters which provides no evidence to a prize puzzle.
Table 4. Identifying sign restrictions

\begin{tabular}{llllll}
\hline & $\begin{array}{l}\text { Exchange } \\
\text { rate }\end{array}$ & $\begin{array}{l}\text { Interest } \\
\text { rate }\end{array}$ & GDP & Price & $\mathrm{M} 1+R$ \\
\hline $\begin{array}{l}\text { Expansionary } \\
\begin{array}{l}\text { monetary } \\
\text { policy }\end{array}\end{array}$ & + & - & NR & NR & + \\
\hline
\end{tabular}

Notes: This table shows the sign restrictions on the impulse responses for each identified shock. ' + ' means that the impulse response of the variable in question is restricted to be positive for two quarters following the shock, including the quarter of impact. Likewise, '-' indicates a negative response. 'NR' indicates that no restrictions have been imposed.

Figure 2 presents the results of the impulse responses of our benchmark VAR model with consumption included as an endogenous variable. The estimation results are obtained placing with sign restrictions for the first two quarters after the shock. The effects of a monetary policy shock to the exchange rate, the price level, the interest rate and the money aggregate are similar to those found in Fig. 1. However, the positive effect of monetary shock to GDP remains significant up to the fourth quarter. The effect of monetary policy shock to consumption is positive and remains significant until the third quarter. After the initial shock, the increase in consumption stays constant up to the second quarters and dips down some. Overall, the positive consumption increase remains persistent for more than 2 years even though it becomes insignificant in the third quarter.

In Fig. 3, the impulse responses of variables to the monetary policy shock are obtained by adding investment into the VAR model with sign restrictions in place. The impulse responses of variables except money to the monetary shock are very similar to 
Table 5. Identifying sign restriction for monetary policy

\begin{tabular}{|c|c|c|c|c|c|c|c|c|c|}
\hline \multicolumn{10}{|c|}{ Mountford (2005) } \\
\hline GDP & Interest rate & \multicolumn{2}{|c|}{ M0 } & \multicolumn{3}{|c|}{ Exchange rate } & \multicolumn{2}{|c|}{ GDP deflator } & Oil price \\
\hline- & + & \multicolumn{2}{|l|}{-} & \multicolumn{2}{|c|}{+} & \multicolumn{3}{|c|}{-} & NR \\
\hline \multicolumn{10}{|c|}{ Mountford and Uhlig (2009) } \\
\hline $\begin{array}{c}\text { Gov. } \\
\text { Revenue }\end{array}$ & $\begin{array}{c}\text { Gov. } \\
\text { Spending }\end{array}$ & \multicolumn{3}{|c|}{$\begin{array}{l}\text { GDP, constant, non- } \\
\text { res inv. }\end{array}$} & \multicolumn{2}{|c|}{ Interest rate } & \multicolumn{2}{|c|}{ Adjusted reserves } & Prices \\
\hline NR & NR & \multicolumn{2}{|c|}{ NR } & & \multicolumn{2}{|l|}{+} & \multicolumn{2}{|r|}{-} & - \\
\hline \multicolumn{10}{|c|}{ Rafiq and Mallik (2008) } \\
\hline GDP & Prices & \multicolumn{2}{|c|}{ Comm. prices } & \multicolumn{2}{|c|}{ Interest rate } & \multicolumn{3}{|c|}{ Money } & Exchange rate \\
\hline NR & - & \multicolumn{2}{|c|}{ NR } & \multicolumn{2}{|c|}{+} & \multicolumn{3}{|c|}{-} & + \\
\hline \multicolumn{10}{|l|}{ Uhlig (2005) } \\
\hline Price & $\begin{array}{c}\text { Nonborrowed } \\
\text { reserves }\end{array}$ & \multicolumn{2}{|c|}{$\begin{array}{l}\text { Federal funds } \\
\text { rate }\end{array}$} & \multicolumn{2}{|c|}{ Reel GDP } & \multicolumn{3}{|c|}{ GDP deflator } & Total reserves \\
\hline- & - & \multicolumn{2}{|c|}{+} & \multicolumn{2}{|c|}{ NR } & \multicolumn{3}{|c|}{ NR } & NR \\
\hline Leelahaphan & $(2009)$ & & & & & & & & \\
\hline GDP & $\begin{array}{l}\text { Annual change } \\
\text { consumer pric }\end{array}$ & & & $\begin{array}{l}\text { Real excl } \\
\text { rate }\end{array}$ & hange & & $\begin{array}{l}\text { ancial se } \\
\text { stock pr }\end{array}$ & $\begin{array}{l}\text { or real } \\
\text { es }\end{array}$ & $\begin{array}{l}\text { Market real } \\
\text { stock prices }\end{array}$ \\
\hline- & - & & & + & & & NR & & NR \\
\hline Kucserová ( & 2009) & & & & & & & & \\
\hline Real output & Price inde & & $\begin{array}{r}1 \\
\text { ective }\end{array}$ & $\begin{array}{l}\text { Nominal } \\
\text { e exchang }\end{array}$ & e rate & & ort-term i & erest rat & \\
\hline- & - & & & + & & & & + & \\
\hline Silva (2008) & & & & & & & & & \\
\hline Prices & Nonborrowec & reserves & & eal GDP & Feder & $1 \mathrm{Ful}$ & ds Rate & $\mathrm{Hol}$ & sing activity \\
\hline- & - & & & - & & + & & & NR \\
\hline Braun and $\mathrm{Sh}$ & aioji (2006) & & & & & & & & \\
\hline $\begin{array}{l}\text { Short term } \\
\text { nominal } \\
\text { interest rate }\end{array}$ & Output & Price & & & $\begin{array}{l}\text { netary } \\
\text { regates }\end{array}$ & & & & \\
\hline+ & - & & - & & - & & (Liqu & ity Effe & t Hypothesis) \\
\hline- & - & & - & & - & & $\begin{array}{l}\text { (Cost } \\
\text { Hypo }\end{array}$ & $\begin{array}{l}\text { Price A } \\
\text { esis) }\end{array}$ & djustment \\
\hline Benati (2008 & & & & & & & & & \\
\hline Short rate & Inflat & & & Output C & Growth & & M4 Gr & & \\
\hline+ & - & & & - & & & & - & \\
\hline
\end{tabular}

Note: non-res inv.: non-residential investment; comm. prices: commodity prices.
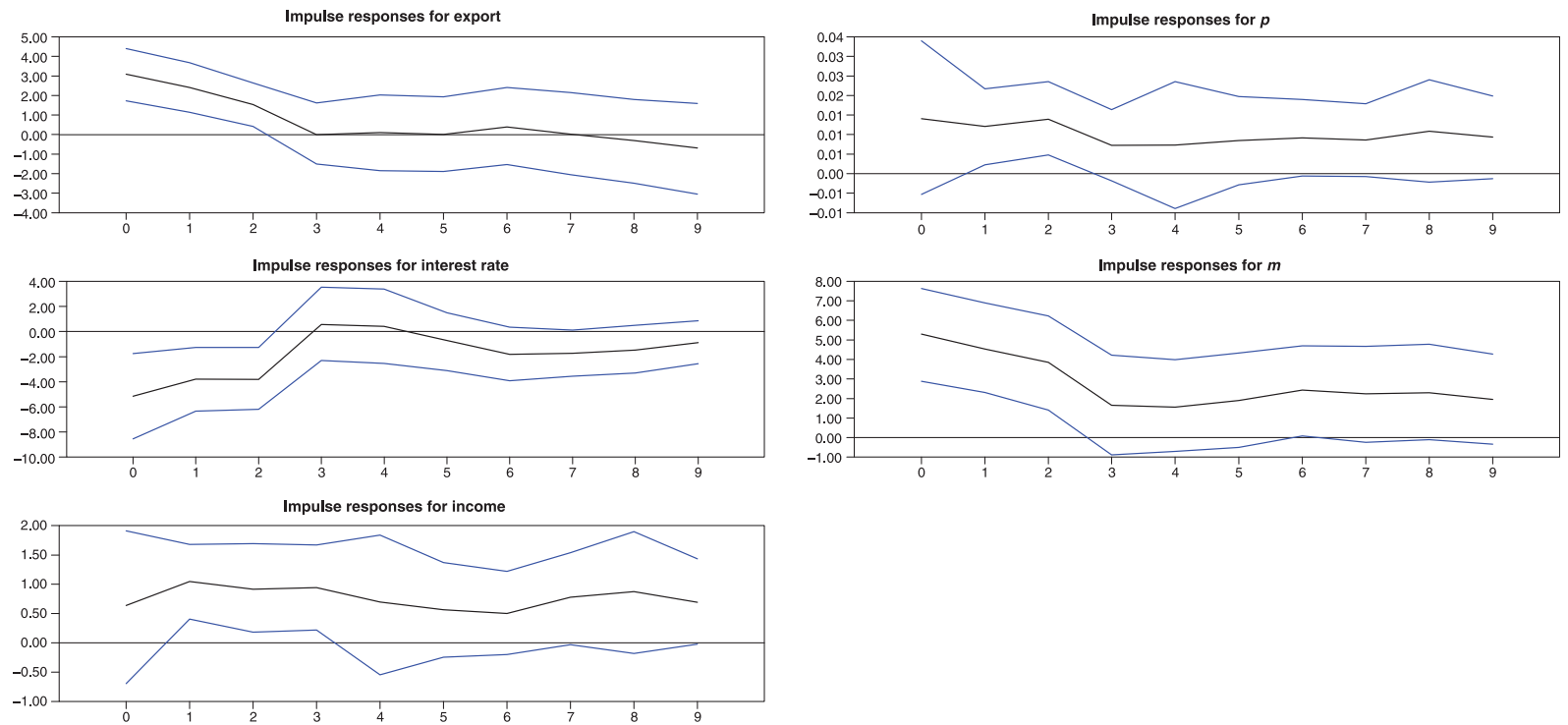

Fig. 1. The effects of monetary policy on income 

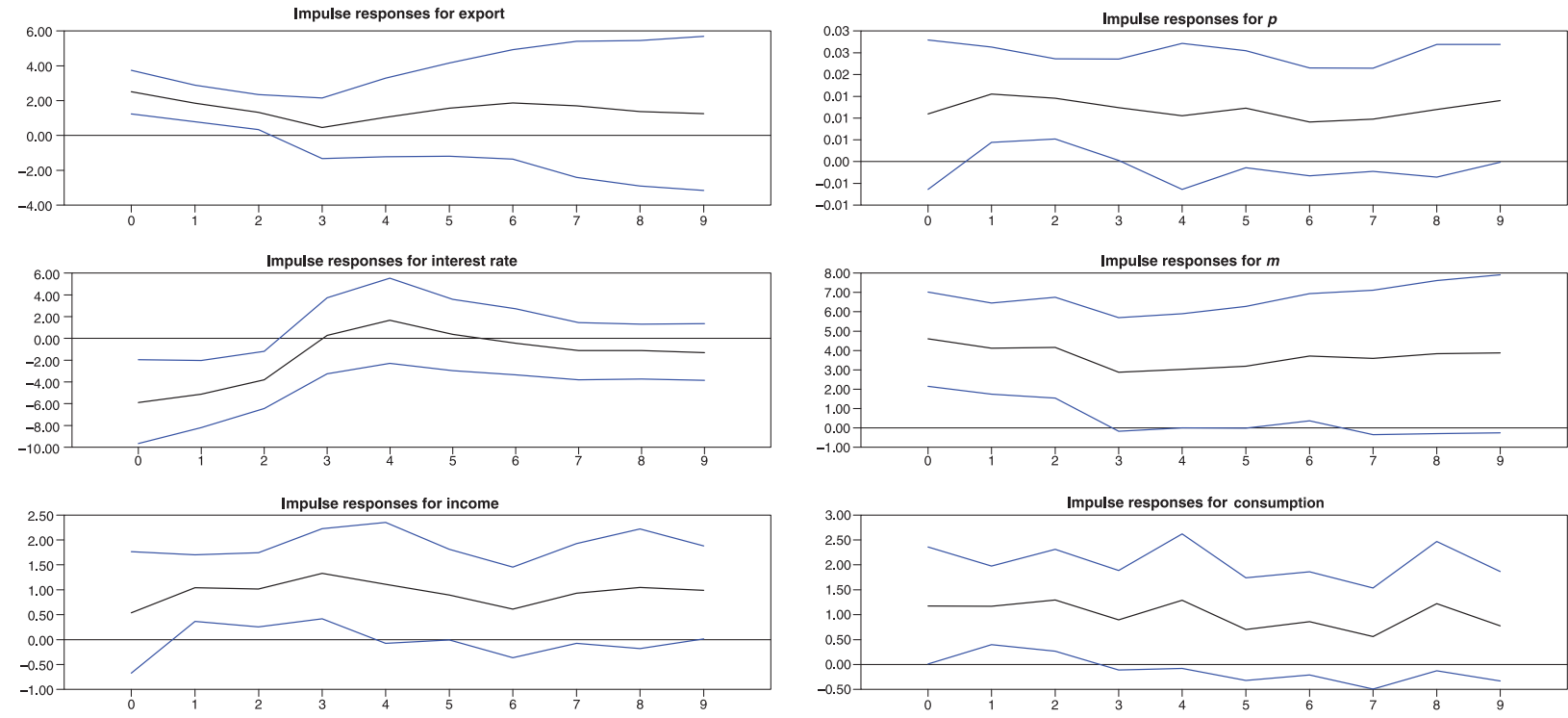

Fig. 2. The effects of monetary policy on consumption
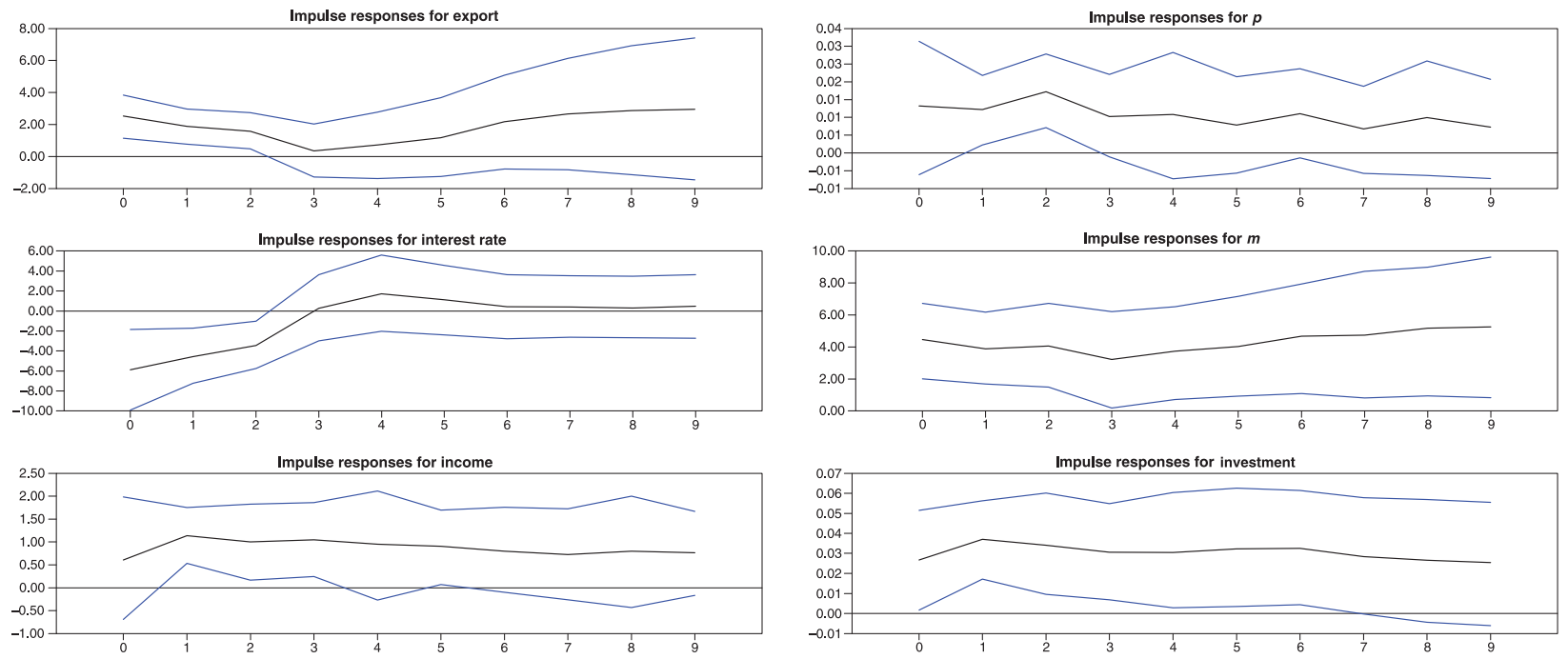

Fig. 3. The effects of monetary policy on investment

those found in Fig. 1. The striking result is that over a longer period, the response of money aggregate to an expansionary monetary policy shock is positive, statistically significant and persistent. The positive investment response to an expansionary monetary policy shock is significant until the seventh quarter. The positive increase in investment is persistent even though it is insignificant after the seven quarters.

Figures 4-7 represent the impulse responses of the benchmark VAR model with government spending, export, import and net trade balance included as an endogenous variable, respectively. The effects of monetary shock to exchange rate, price level, interest rate, money aggregate and income are similar to those found in the Fig. 1. A shock in the monetary policy has a positive effect on government spending. The positive increase peaks at the second quarter and then dies out after the fourth quarter and this effect is statistically significant at the margin in the second period. The effect on export is positive and persistent. It should be observed that the rise in export is statistically significant after two periods. This is not surprising that loose monetary policy will, through its downward effect on the domestic interest rate, reduce the exchange rate and thereby increase exports (Olekalns, 2002). In response to a monetary policy shock, the import significantly rises until the fourth period. Finally, the trade balance falls in third period 

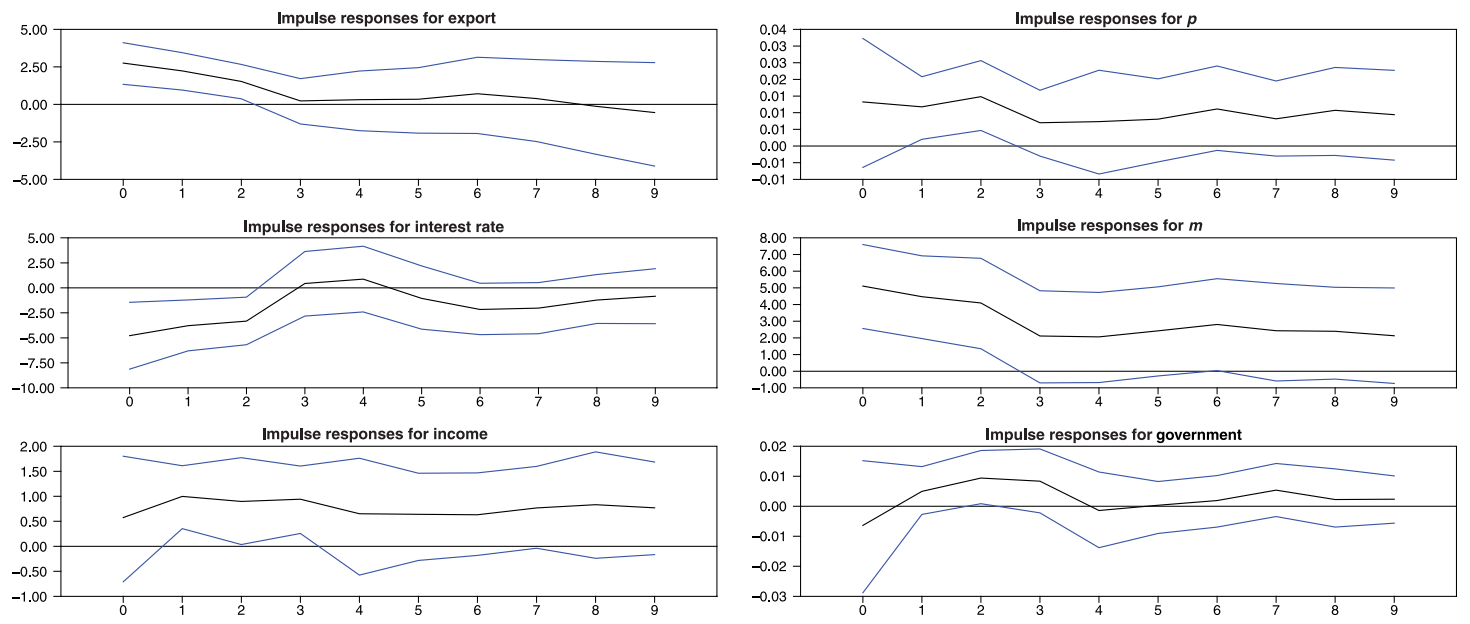

Fig. 4. The effects of monetary policy on government spending
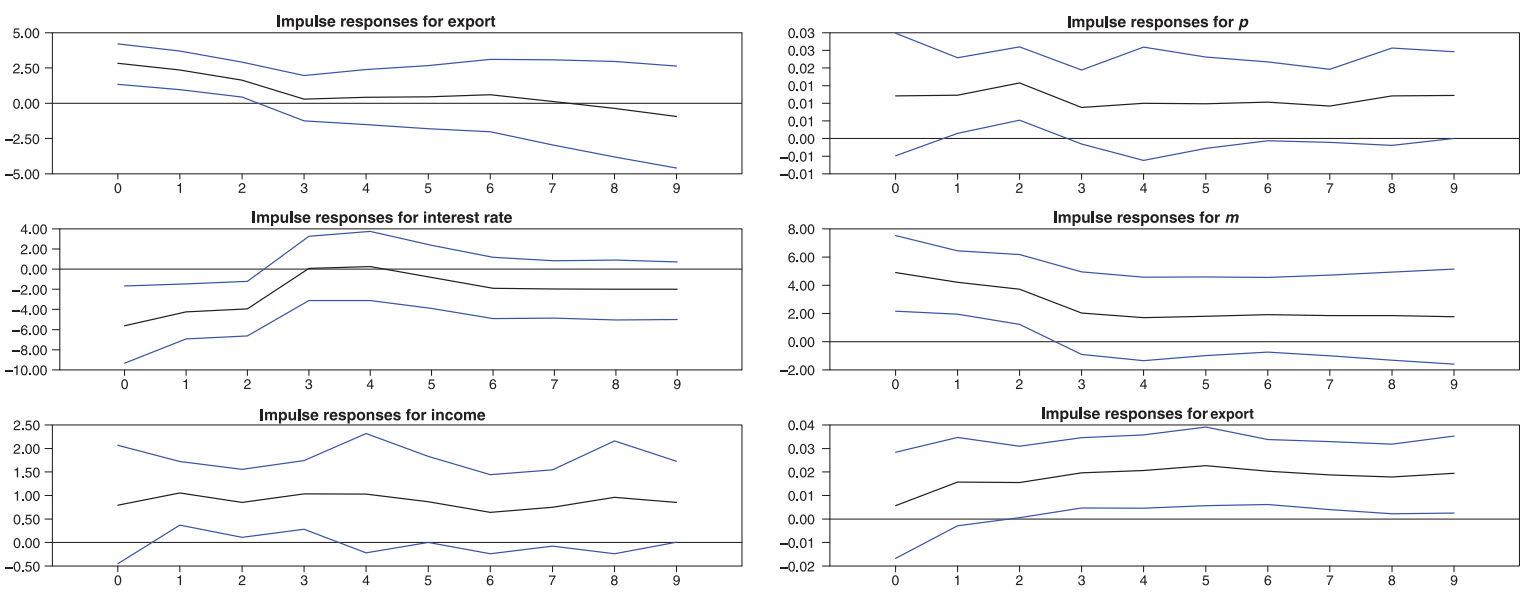

Fig. 5. The effects of monetary policy on export
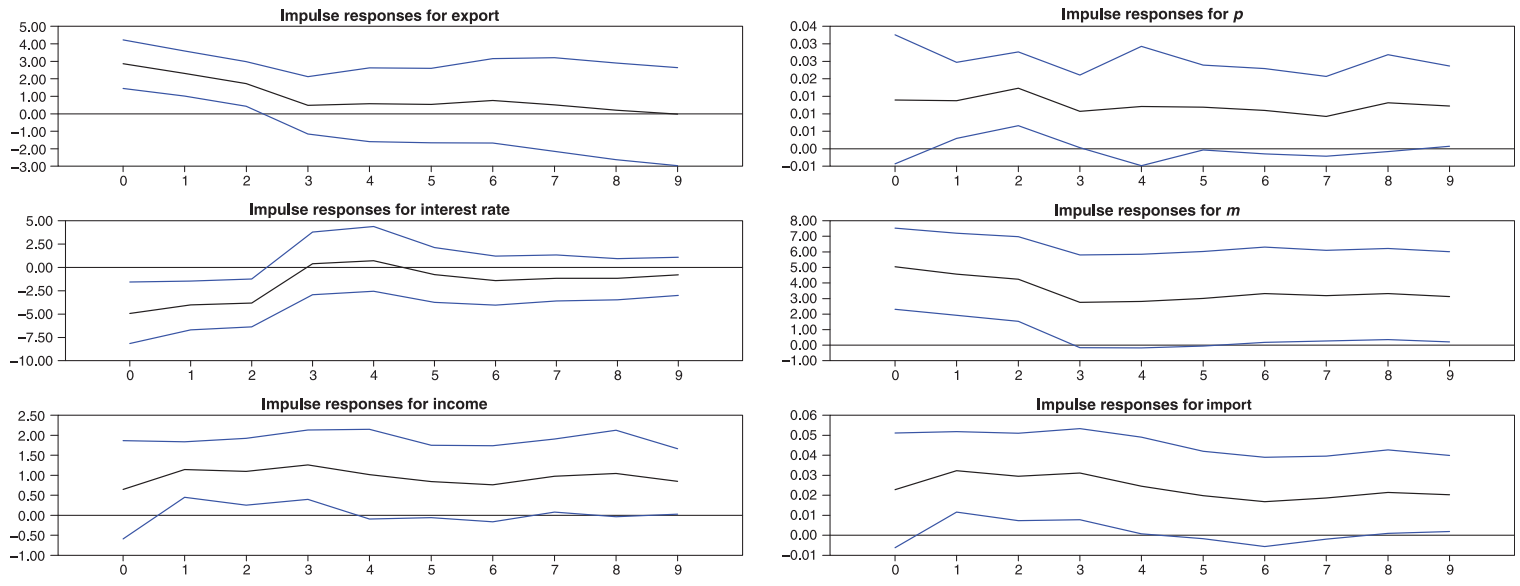

Fig. 6. The effects of monetary policy on import 

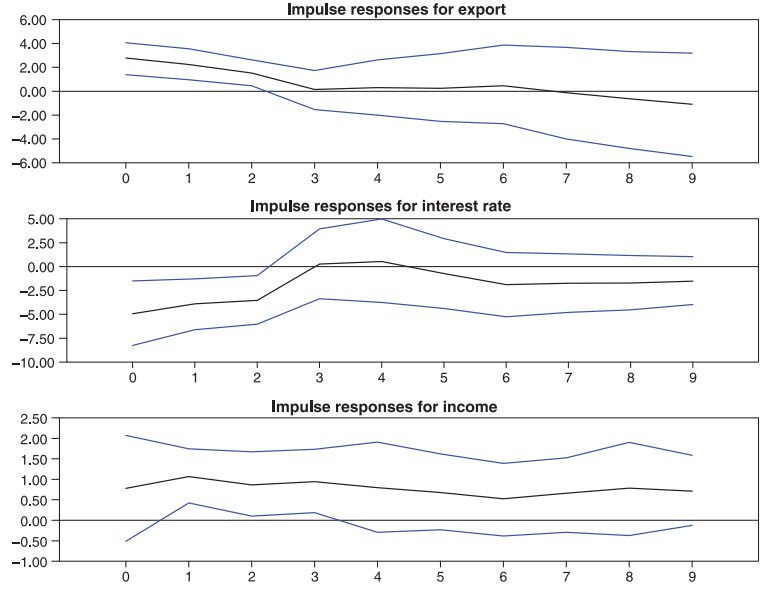

Fig. 7. The effects of monetary policy on trade balance
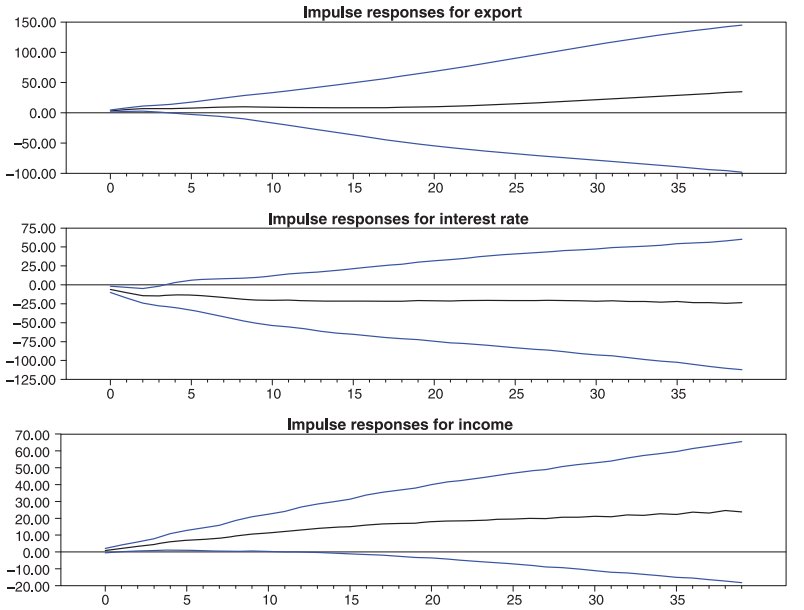

Fig. 8. The accumulated effects of monetary policy on income

and then rises for the five periods; the confidence intervals are large enough, and thus the effect is not statistically significant.

In order to assess the long-run effect of monetary policy shocks on output and its components, we report accumulated impulse responses as in studies by Blanchard and Perotti (2002), Freo (2005), Ramos and Roca-Sagales (2008) and Mountford and Uhlig (2009). Figure 8 reports the accumulated impulse responses of monetary policy shocks on our benchmark model for 40 periods (10 years). Monetary policy shock does not have any effect on the variables of interest in the benchmark VAR model at the end of 40th period. It might be surprising that monetary policy shock does not even affect prices. However, note that, a shock to monetary policy does not have persistent effect on money aggregate in 40 periods. Thus, one may expect that since money aggregate is
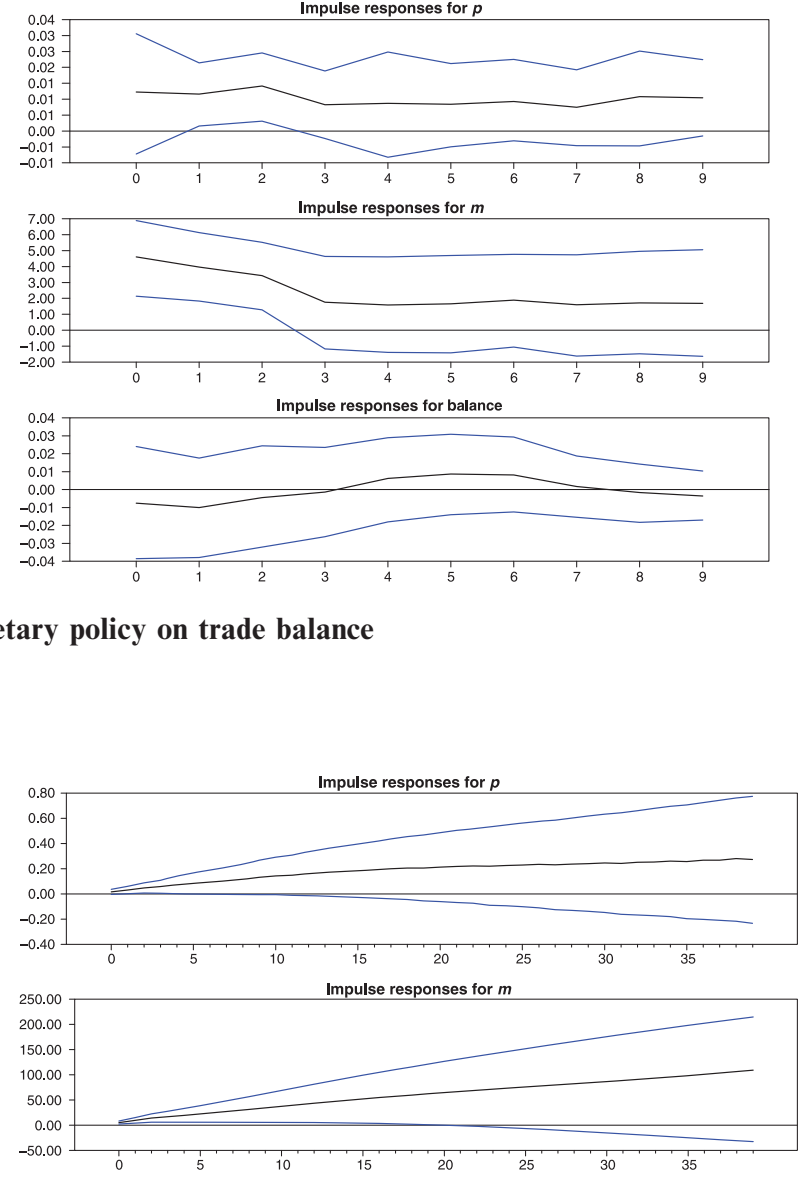

not affected permanently, the prices should not be affected permanently. Next, Fig. 9 reports the accumulated impulse responses of monetary policy shocks on each component of the output. Again, the effects of monetary policy shocks on output components were not there: Money is neutral in the long-run.

\section{Conclusion}

The aim of this article is to estimate the effects of monetary policy shocks on the component of aggregate demand in Turkish economy. In order to identify the monetary policy innovations, this study uses a new sign restriction approach pioneered by Uhlig (2005). There is a wide consensus that an expansionary monetary policy shock does not lead to a decrease 

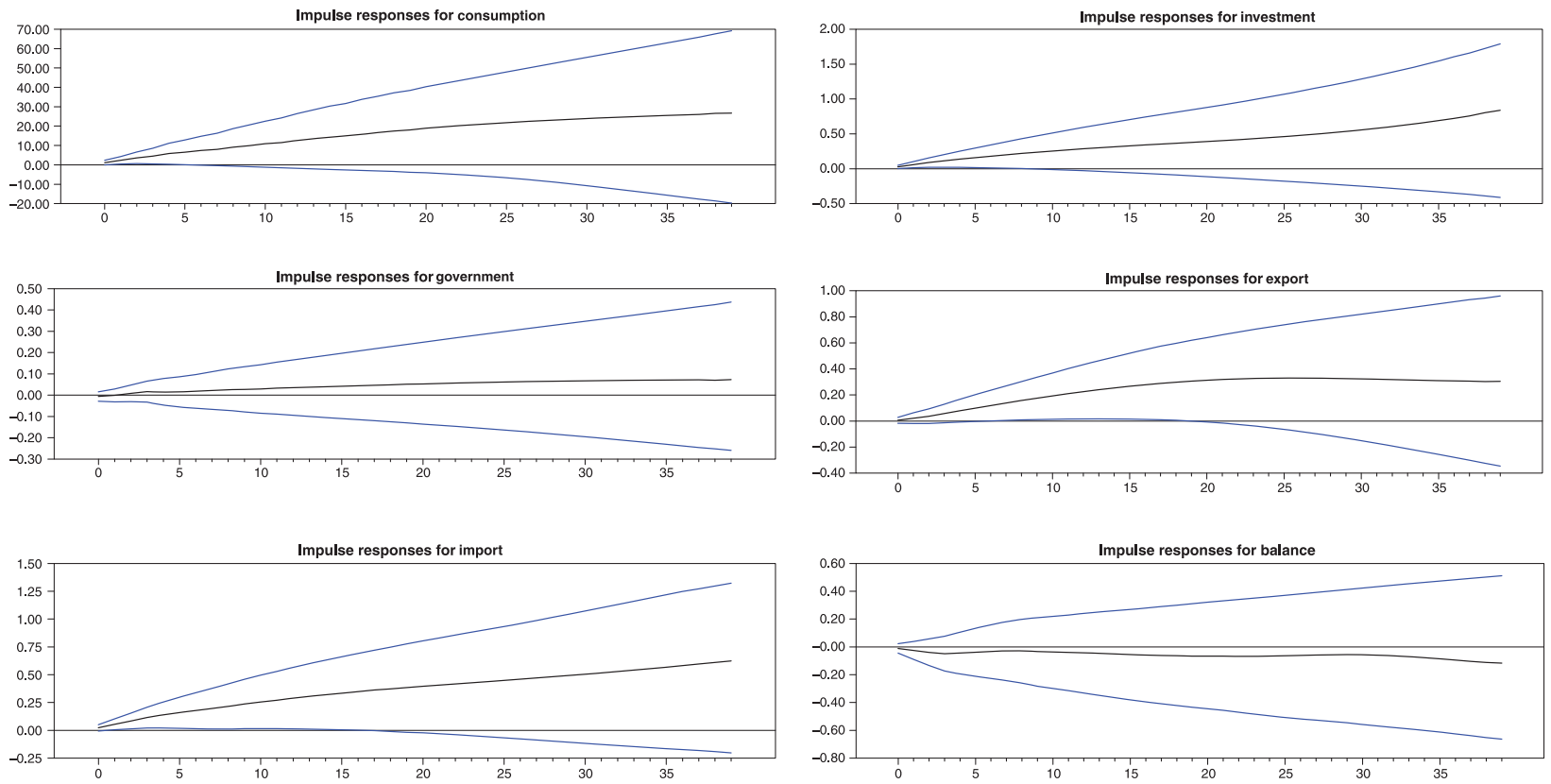

Fig. 9. The accumulated effects of monetary policy on income components

in the exchange rate, the money aggregate or increase in the interest rate for a certain period. There are no restrictions placed on the responses of the GDP and the price level. Using these restrictions, we obtain impulse responses of each variable in VAR model.

Overall, the results show that the expansionary monetary policy leads to increase in both price and income in the short-run. Since the positive price increase is present, there is no evidence to a prize puzzle in Turkish economy. The response of money aggregate to an expansionary monetary policy shock is positive, statistically significant, so the effect on liquidity is present. There is a statistically significant positive consumption and investment response to loose monetary shock in the short-run. The effect of expansionary policy on government spending is also positive but statistically significant at the margin. The export and import are also positively affected. The monetary policy shock has a negative effect on trade balance, but these effects are not statistically significant. On the other hand, expansionary monetary policy is ineffective for output and its component in the long-run. It means that money is neutral in the long-run.

\section{Acknowledgements}

We would like to thank to The Turkish Scientific and Technological Research Council for their partial financial support that allowed Yeliz Yalcin to visit
Valdosta State University that made this research possible (program code:2219).

\section{References}

Benati, L. (2008) The great moderation in the United Kingdom, Journal of Money, Credit, and Banking, 40, $121-47$.

Bernanke, B. and Blinder, A. (1992) Federal funds rate and the channels of monetary transmission, American Economic Review, 82, 901-21.

Berument, H. (2007) Measuring monetary policy for a small open economy: Turkey, Journal of Macroeconomics, 29, 411-30.

Blanchard, O. J. and Perotti, R. (2002) An empirical characterization of the dynamic effects of changes in government spending and taxes on output, Quarterly Journal of Economics, 117, 1329-68.

Braun, R. A. and Shioji, E. (2006) Monetary policy and the term structure of interest rates in Japan, Journal of Money, Credit, and Banking, 38, 141-62.

Christiano, L. J. and Eichenbaum, M. (1992) Liquidity effects and the monetary transmission mechanism, American Economic Review, 82, 346-52.

Coricelli, F., Mucci F. and D. Revoltella (2006) Household credit in the New Europe: lending boom or sustainable growth?, CEPR Discussion Paper No. 5520.

Dickey, D. A. and Fuller, W. A. (1981) Likelihood ratio statistics for autoregressive time series with a unit root, Econometrica, 49, 1057-72.

Dickinson, D. G. and Liu, J. (2007) The real effects of monetary policy in China: an empirical analysis, China Economic Review, 18, 87-111.

Freo, M. (2005) The impact of sales promotions on store performance: a structural vector autoregressive 
approach, Statistical Methods and Applications, 14, 271-81.

Friedman, M. (1969) The role of monetary policy, American Economic Review, 59, 1-10.

Jang, K. and Ogaki, M. (2004) The effects of monetary policy shocks on exchange rates: a structural vector error correction model approach, Journal of Japanese and International Economies, 18, 99-114.

Johansen, S. and Juselius, K. (1990) Maximum likelihood estimation and inference on cointegration with applications for the demand for money, Oxford Bulletin of Economics and Statistics, 52, 169-210.

Kwiatkowski, D., Phillips, P. C. B., Schmidt, P. and Shin, Y. (KPSS) (1992) Testing the null hypothesis of stationarity against the alternative of a unit root: how sure are we that the economic time series have a unit root?, Journal of Econometrics, 54, 159-78.

Kucserová, J. J. (2009) Effects of monetary policy shocks in Slovakia, Discussion Paper No. 1/2009, National Bank of Slovakia.

Leelahaphan, T. (2009) Monetary policy, exchange rate and Asian stock markets, in Singapore Economic Review Conference, Singapore. Available at http://editorialexpress.com/conference/serc2009/program/serc2009.html (accessed 6 April 2011).

Lütkepohl, H. and Reimers, H. E. (1992) Granger causality in cointegrated VAR processes: the case of the term structure, Economics Letters, 40, 263-8.

MacKinnon, J. G., Haug, A. A. and Michelis, L. (1999) Numerical distribution functions of likelihood ratio tests for cointegration, Journal of Applied Econometrics, 14, 563-77.

Mishkin, F. S. (2001) The transmission mechanism and the role of asset prices in monetary policy, NBER Working Paper Series No. 8617.

Mishkin, F. S. (2006) Monetary policy strategy: how did we get here?, NBER Working Paper No. 12515.

Mountford, A. (2005) Leaning into the wind: a structural VAR investigation of UK monetary policy, Oxford Bulletin of Economics and Statistics, 67, 597-621.
Mountford, A. and Uhlig, H. (2009) What are the effects of fiscal policy shocks?, Journal of Applied Econometrics, 24, 960-92.

Olekalns, N. (2002) The macroeconomic implications of current fiscal policy, Australian Economic Review, 31, 66-72.

Perron, P. (PP) (1989) The great crash, the oil price shock, and the unit root hypothesis, Econometrica, 57, $1361-401$

Rafiq, M. S. and Mallick, S. K. (2008) The effect of monetary policy on output in EMU3: a sign restriction approach, Journal of Macroeconomics, 30, 1756-91.

Ramos, X. and Roca-Sagales, O. (2008) Long-term effects of fiscal policy on the size and distribution of the pie in the UK, Fiscal Studies, 29, 387-411.

Samkharadze, B. (2008) Monetary transmission mechanism in Georgia: analyzing pass-through of different channels, National Bank of Georgia Working Paper No. 2.

Silva, C. V. (2008) Monetary policy and the US housing market: a VAR analysis imposing sign restrictions, Journal of Macroeconomics, 30, 977-90.

Sims, C. A. (1972) Money, income and causality, American Economic Review, 62, 540-52.

Sims, C. A. (1980) Macroeconomics and reality, Econometrica, 48, 1-48.

Sims, C. A. (1992) Interpreting the macroeconomic time series facts, European Economic Review, 36, 975-1011.

Sims, C. A., Stock, J. H. and Watson, M. (1990) Inference in linear time series models with some unit roots, Econometrica, 58, 113-44.

Sims, C. A. and Uhlig, H. (1991) Understanding unit rooters: a helicopter tour, Econometrica, 59, 1591-600.

Tobin, J. (1969) A general equilibrium approach to monetary theory, Journal of Money, Credit and Banking, 1, 15-29.

Uhlig, H. (1994) What macroeconomists should know about unit roots: a Bayesian perspective, Econometric Theory, 10, 645-71.

Uhlig, H. (2005) What are the effects of monetary policy on output? Results from an agnostic identification procedure, Journal of Monetary Economics, 52, 381-419. 